International Business and Global Economy 2018, no. 37, pp. 157-167

Biznes międzynarodowy w gospodarce globalnej 2018, nr 37, s. 157-167

Edited by the Institute of International Business, University of Gdańsk

\title{
Non-equity modes w erze digitalizacji gospodarki
}

Celem artykułu jest próba odpowiedzi na pytanie o wpływ cyfryzacji na zakres podejmowania pozakapitałowych form (NEMs) w ekspansji zagranicznej przedsiębiorstw, czyli o to, jakie tworzy ona bariery i jakie przynosi korzyści. W artykule zastosowano metodę opisową oraz wykorzystano badania ankietowe przeprowadzone $\mathrm{w}$ grupie polskich producentów sektora IT. $Z$ badań wynika, że NEMs mają niewielkie znaczenie $w$ internacjonalizacji polskich przedsiębiorstw sektora IT. W dużej mierze wiąże się to z niedostrzeganiem przez przedsiębiorstwa korzyści wynikających z cyfryzacji biznesu w ekspansji zagranicznej, ale także ze specyfiką sektora (małe możliwości kapitałowe i niewielkie międzynarodowe doświadczenie). Tworzenie sieci powiązań biznesowych poprzez eksport pośredni (wiodąca forma ekspansji wśród badanych firm) oraz wykorzystanie środowiska cyfrowego mogą stanowić podstawę dalszego rozwoju NEMs w ekspansji zagranicznej przedsiębiorstw.

Słowa kluczowe: NEMs, internacjonalizacja, digitalizacja

Klasyfikacja JEL: F21, F23

\section{Non-equity modes in the digital era}

The aim of the paper is to reveal the impact of digitization on the scope of non-equity modes (NEMs) in the internationalization process, its barriers and benefits. The study uses a descriptive method and the results of a survey conducted in the group of Polish IT producers. The research shows that NEMs do not affect the internationalization of Polish IT producers significantly. This is due to the fact that enterprises do not see the benefits of business digitization in foreign expansion, but also to the specificity of the sector (low capital opportunities and little international experience). Business relationship networks created through indirect export (the leading form of expansion among the surveyed companies) together with the use of digital environment can provide conditions for the development of non-equity forms in their foreign expansion.

Keywords: non-equity modes (NEMs), internationalization, digitization

JEL classification: F21, F23 


\section{Wprowadzenie}

Na przełomie wieków XX i XXI dużą rolę w rozwoju transnarodowych korporacji (KTN) przypisuje się formom Non-equity modes (NEMs), na które składają się: produkcja na zamówienie (contract manufacturing) według specyfikacji korporacji transnarodowych, umowy z farmerami na produkcję produktów rolnych (contract farming), outsourcing, franczyza, licencje, kontrakty menedżerskie oraz wszystkie pozostałe formy kontraktu [WIR, 2011, s. 123-125]. Traktowane są one jako komplementarne wobec inwestycji kapitałowych, przez które KTN koordynują globalną kreację wartości i wpływają na zarządzanie w firmach krajów goszczących bez zaangażowania kapitałowego. Postępująca cyfryzacja gospodarki znacznie zmienia jednak uwarunkowania ekspansji zagranicznej przedsiębiorstw, co implikuje zmiany w podejściu do wyboru jej form, choć te współzależności, tj. digitalizacja - formy ekspansji zagranicznej przedsiębiorstwa, są jeszcze słabo $w$ literaturze przedmiotu rozpoznane. Stąd też celem artykułu jest próba udzielenia odpowiedzi, jakie korzyści i bariery wiążą się z wykorzystaniem NEMs jako formy ekspansji zagranicznej w erze cyfryzacji. Rozważania, ze względu na brak porównywalnych danych statystycznych na temat NEMs, mają charakter teoretyczny, zostały jednak częściowo zweryfikowane wynikami badań ankietowych przeprowadzonych w grupie polskich eksporterów IT. Wybór tych ostatnich wynika z faktu, iż sektor IT charakteryzuje się szczególną podatnością na zastosowanie rozwiązań cyfrowych, lecz w Polsce, na tle innych państw europejskich, odznacza się niską innowacyjnością. U podstaw rozważań znajduje się teza: przedsiębiorstwa IT w Polsce nie postrzegają cyfryzacji jako narzędzia do rozwoju pozakapitałowych form ekspansji zagranicznej i związanych z tym korzyści.

\section{Digitalizacja w optyce biznesu międzynarodowego}

Pojęcie digitalizacji, choć powszechnie stosowane, jest niejednoznaczne i jego definicja zmienia się w czasie. Mnogość ujęć stanowi w dużym stopniu efekt nieustannej rewolucji informatycznej. Pierwsze koncepcje [Bukht, Heeks, 2017, s. 13] koncentrowały się na Internecie, późniejsze włączają do definicji gospodarki cyfrowej technologie mobilne, chmury obliczeniowe i duże zbiory danych. Według Rumany Bukhta i Richarda Heeksa [Bukht, Heeks, 2017, s. 13] gospodarka cyfrowa składa się z trzech obszarów:

- rdzenia tworzonego przez sektor ICT,

- zakresu wąskiego - ICT wraz z usługami platform cyfrowych, 
- ujęcia szerokiego - gospodarkę cyfrową dodatkowo tworzą technologie cyfrowe umożliwiające takie aktywności, jak: handel elektroniczny (e-commerce), biznes elektroniczny (e-business), automatyka i sztuczna inteligencja, gospodarka współdzielenia (sharing economy) (np. Uber i Airbnb) oraz internetowe platformy robocze (np. Upwork i Amazon Mechanical Turk).

We wszystkich obszarach digitalizacji występują nowe produkty, tj. produkty cyfrowe, które w odróżnieniu od tradycyjnych są bardziej złożone i występują w dwóch formach [Wieczerzycki, 2015, s. 135-140]: jako czyste produkty (np. programy komputerowe) lub konwertowane produkty cyfrowe (np. e-booki, pliki muzyczne, graficzne, tekstowe). Produkty cyfrowe zapisywane są na fizycznym nośniku, stanowiącym jednocześnie materialny wymiar produktu cyfrowego. Każda informacja może być wielokrotnie zapisana, stanowiąc tym samym odrębny egzemplarz produktu cyfrowego. Stąd też produkty cyfrowe mogą mieć zarówno charakter niematerialny, jak i materialny. Ta specyfika produktu rzutuje na sposób dystrybuowania i bariery wejścia na rynki zagraniczne. W przypadku produktu cyfrowego niematerialnego są to przede wszystkim (choć nie tylko) ograniczenia instytucjonalne (regulacje w kraju goszczącym - instytucje formalne, jak też obawa przed piractwem - instytucje nieformalne) oraz infrastrukturalne (brak dostępu do sieci czy ograniczone możliwości płatności online). W przypadku produktów cyfrowych materialnych bariery wejścia na rynki zagraniczne należy postrzegać tak samo jak w odniesieniu do produktów niecyfrowych.

Z wąskim postrzeganiem digitalizacji (sektor ICT wraz z usługami platform) wiążą się duże zmiany w kształtowaniu międzynarodowego środowiska biznesowego. Z reguły ekosystem platform ukierunkowany jest na wykładniczy wzrost, co pozwala na omijanie w ten sposób malejących przychodów związanych z wykorzystaniem tradycyjnych modeli biznesowych i coraz częściej odgrywa strategiczną rolę we wszystkich rodzajach firm, zarówno opartych na aktywach rzeczowych (np. Philips, GE) i niematerialnych (Google i Uber), jak też łączących platformy ekosystemów z aktywami rzeczowymi (Apple i Amazon) [Pakulska, 2017, s. 30].

Przedsiębiorstwa mogą prowadzić działalność w oparciu o ogólnodostępne platformy lub tworzyć własne. Niezależnie jednak od ich charakteru tworzona wartość stanowi efekt łączenia zasobów (własnych i/lub dostępnych) z efektami sieciowymi. Firma działająca w sieci uzyskuje bowiem dostęp (niekiedy ograniczony) do zasobów zewnętrznych, którymi dysponują inne firmy przynależące do sieci (zasoby rynkowe). Możliwość ich pozyskania zależy od pozycji firmy w sieci oraz jej struktury (ukształtowanego charakteru współzależności). Tego typu możliwości wykorzystują w pierwszej kolejności duże korporacje z sektora IT, których szkieletem budowy strategii wejścia na rynki zagraniczne są właśnie platformy [Poniatowska-Jaksch, 2016, s. 171-172]. W 2016 r. aż pięć korporacji 
z sektora IT uplasowało się w pierwszej dziesiątce największych światowych graczy (Apple, Alphabet, Microsoft, Amazon i Facebook) [Gray, 2017].

Platformy z perspektywy biznesu
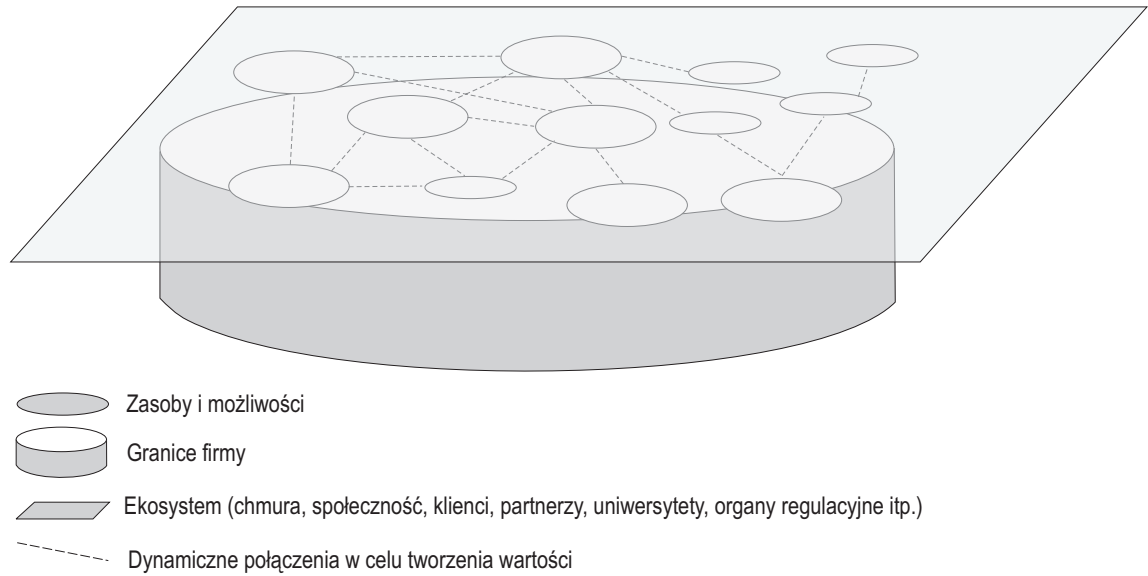

System z perspektywy biznesu

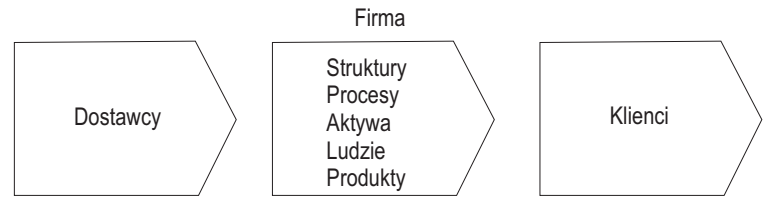

Rysunek 1. Platforma w optyce biznesu

Źródło: [Gartner, 2016, s. 2].

Z szerokim spojrzeniem na digitalizację wiążą się nowe, nieznane w gospodarce tradycyjnej, rodzaje aktywności gospodarczej. Wysoką dynamiką cechuje się zwłaszcza e-commerce, $\mathrm{w}$ wymiarze międzynarodowym (tzw. transgraniczny e-commerce) w dużym stopniu zdominowany przez kilka firm (Amazon, Alibaba, Otto, Walmart wraz z GroupOn, Zalando, Rakuten oraz eBay) [MBASkool, 2017], z których pośrednictwa korzystają nie tylko osoby fizyczne, ale także przedsiębiorstwa, zwłaszcza MSP. Rozwój transgranicznego e-commerce napotyka pewne bariery, którym trudniej jest sprostać mniejszym firmom. Na rynku europejskim najczęściej wskazuje się w tym zakresie na bariery: wejścia na rynek (np. koszty budowy świadomości marki), regulacji (reklama, dopuszczenia do sprzedaży itp.), logistyki oraz lokalizacji [Poczta Polska, 2017]. Innymi słowy, era cyfryzacji gospodarki to m.in. okres dynamicznego rozwoju korporacji transnarodowych w systemie platform, których znacznym źródłem dochodów jest pośrednictwo w handlu zagranicznym. 


\section{Rola NEMs w usieciowionej gospodarce}

NEMs traktowane są jako alternatywa kontrolowania przez KTN łańcucha globalnej wartości (global value chains - GVCs) [WIR, 2011, s. 123-125]. Stanowią one pośrednie formy ekspansji międzynarodowej między pierwszym jej etapem, czyli eksportem, a jej formą najbardziej zaawansowaną. tj. BIZ. W modelach non-equity istotne są:

- możliwość sprawowania kontroli przez korporacje transnarodowe nad firmami-partnerami;

- kształtowanie relacji w sieci głównie w oparciu o powiązania kontraktowe, a nie kapitałowe (własnościowe) - nie jest to jednak podział jednoznaczny, gdyż nie wszystkie powiązania kontraktowe są w pełni nie kapitałowe;

- wkład kapitałowy, który (o ile występuje) najczęściej sprowadza się do aportu rzeczowego oraz know-how. W praktyce gospodarczej może to przybierać formy minority joint venture.

NEMs poprzez swą istotę $\mathrm{i}$ cechy (zmiana horyzontu czasowego zawieranych kontraktów, rosnąca złożoność zakresu i sposobu formalizacji powiązań partnerskich, zmienność ich intensywności między partnerami kontraktu, wzrost znaczenia powiązań nieformalnych) stanowią specyficzną formę internacjonalizacji sieciowej, w której kreatorem sieci mogą być zarówno jednostki macierzyste, jak też ich filie. Proces tak postrzeganej internacjonalizacji jest zawsze $w$ pewnym stopniu nieprzewidywalny, a nieprzewidywalność ta wzrasta wraz ze wzrostem autonomii filii oraz liczby partnerów powiązanych z korporacjami w sposób non-equity.

Nowe warunki w tym zakresie niesie ze sobą digitalizacja gospodarki zarówno wąsko, jak i szeroko postrzegana. Internet i zmiana charakteru produktu z materialnego na cyfrowy - umożliwiły KTN wirtualizację globalnych łańcuchów wartości. Skutkiem zmian dokonujących się w wyniku wirtualizacji jest wzrost efektywności funkcjonowania przedsiębiorstw [Chen, 2005, s. 16-18]. Elektroniczne sieci umożliwiają tworzenie płynnie zintegrowanego łańcucha wartości, łączącego źródła zaopatrzenia ze znajdującymi się na końcu klientami. Wpływa to nie tylko na zmniejszenie kosztów transakcyjnych, ale także na szybszy i lepszy przepływ informacji między wszystkimi elementami łańcucha wartości [Wymbs, 2000, s. 463-477]. Na poziomie właściwie każdego elementu tworzącego łańcuch wartości firmy możliwe jest podejmowanie działań z jednej strony wprowadzających nowe moduły biznesowe (ściśle powiązane z funkcjonowaniem Internetu, sieciowością), z drugiej zaś eliminujących moduły tradycyjne, związane z tzw. gospodarką przedinternetową. Dodatkowo Internet umożliwia fizyczne skracanie łańcucha wartości. Modelowanie i zmiana konfiguracji (w każdym możliwym układzie) dotychczasowych powszechnie znanych narzędzi biznesowych 
jest kolejną metodą rozwoju biznesów internetowych w dynamicznym środowisku rynkowym bez granic [Pakulska, Poniatowska-Jaksch, 2016, s. 223-229].

W tradycyjnej gospodarce transgraniczne NEMs gwarantują KTN kontrolę różnego typu organizacji biznesowych poza krajem macierzystym, której poziom i zakres niekiedy bywa porównywalny z takim, jaki gwarantują powiązania kapitałowe. Firmy partnerskie bardzo ściśle współpracują z korporacjami, gdyż charakter i zakres tej współpracy pozwala zwiększyć korzyści uzyskiwane ze współdziałania w sieci. Im ściślejsza współpraca, tym większa kontrola korporacji nad działaniami firm partnerskich. Stąd też niekiedy te ostatnie postrzegane są wręcz jako filie korporacji transnarodowych. Takiemu podejściu do firm partnerskich towarzyszy, jak w przypadku BIZ, przepływ niektórych aktywów, zasobów, technologii i know-how z korporacji do partnerów kontraktowych w celu jak najlepszego zabezpieczenia ich działalności w kraju goszczącym. Zakres tego typu przepływów zdeterminowany jest modelem non-equity. Niemniej jednak satysfakcjonujący KTN poziom kontroli w zarządzaniu globalnym łańcuchem wartości poprzez formy non-equity wykreował tzw. puste przedsiębiorstwa [Sala, 2005, s. 38] oraz zahamował wydatki przede wszystkim na inwestycje typu greenfield investment.

Wirtualizacji globalnych łańcuchów wartości towarzyszy wzrost liczby fuzji i przejęć oraz inwestycji KTN w startupy - rośnie rola kapitałowych form wejścia na rynki zagraniczne. Dokonywane są one głównie w celu: wejścia na nowe rynki lub poszerzenia już istniejących poprzez tworzenie oferty pakietowej, nabycia praw do innowacyjnych rozwiązań dostarczających rewolucyjnych technologii czy też eliminacji potencjalnego ryzyka. Komplementarną formą wejścia wobec BIZ jest m.in. transgraniczny e-commerce, w zakresie którego przedsiębiorstwa stosują różne rozwiązania:

- wykorzystanie Internetu jako dodatkowego źródła przychodów (Walmart, Best Buy),

- łączenie sprzedaży online i offline (np. Otto Group),

- korzystanie z usług światowych pośredników (np. takich jak Amazon) - praktykowane zwłaszcza w grupie mniejszych przedsiębiorstw.

W erze digitalizacji nieco odmiennie przedstawia się kwestia kontroli, produkty cyfrowe charakteryzuje bowiem wysoka trwałość i ich upodabnianie się wraz z upływem czasu do dóbr o charakterze publicznym. Zjawisko to w dłuższym okresie prowadzi do wzrostu liczby dostępnych na rynku produktów cyfrowych, w tym też nielegalnych (piractwo), a następnie spadku ich cen. W takich warunkach niezwykle ważne jest zapewnienie kontroli nad dystrybucją swoich produktów przez patentowanie i ochronę praw autorskich, a jedną z ważniejszych form ekspansji zagranicznej, komplementarną wobec powiązań kapitałowych, stanowią licencje. 


\section{NEMs w praktyce polskich producentów IT}

Ukierunkowanie ekspansji na wykorzystanie cyfrowych kanałów, przy dostosowanej do potrzeb i możliwości przedsiębiorstwa architekturze IT, oznacza nowy sposób tworzenia i dostarczania wartości dla klienta, ekspansji zagranicznej, pokonywania jej barier i poszukiwania źródeł przewagi konkurencyjnej (m.in. poprzez zdolności IT i poprawę zarządzania ryzykiem jako efekt spójności i niezawodności systemów oraz poprawy zabezpieczeń). Podatność sektora IT na implementację rozwiązań cyfrowych skłania do oceny, na ile stosowane są one $\mathrm{w}$ podejmowanych przez przedsiębiorstwa pozakapitałowych formach ekspansji zagranicznej. Do ich częściowej weryfikacji wykorzystano wyniki badań przeprowadzonych w lipcu 2017 r. metodą wywiadów telefonicznych ze wspomaganiem komputerowym CATI (Computer Assisted Telephone Interview) na reprezentatywnej próbie 131 przedsiębiorstw - polskich producentów IT ${ }^{1}$. Spośród objętych badaniem nieco ponad połowę stanowily przedsiębiorstwa produkcyjne (53\%), dla pozostałych dominującą działalnością były usługi. Większość badanych (59\%) według kryterium wielkości rocznych obrotów stanowiły mikroprzedsiębiorstwa, co wraz z małymi i średnimi przedsiębiorstwami stanowiło ok. 95\% badanych (85\% według kryterium zatrudnienia).

Niewiele badanych firm $\mathrm{w}$ swoich strategiach wejścia na rynki zagraniczne wykorzystuje inne niż eksport formy internacjonalizacji, zarówno kapitałowe, jak i pozakapitałowe (14\% respondentów sprzedaje licencje, $1 \%$ działa na zasadzie franczyzy). Nie planują też ich wdrożenia w warunkach cyfryzacji biznesu (98\%). Pozostaje to w sprzeczności z istniejącymi trendami, gdyż druga dekada XXI w. to era integracji ekosystemów biznesowych [Sagan, 2017, s. 88] oraz internacjonalizacji przedsiębiorstw, których niejako „szkieletem” są platformy internetowe. To niewielkie jeszcze wykorzystanie technologii ICT w ekspansji zagranicznej przez dominujące w badaniu MSP tego sektora wiąże się niewątpliwie z faktem, że jako dostawcy rozwiązań IT de facto nie znają potrzeb obecnych i potencjalnych odbiorców (główny odbiorca ich produktów, tj. MSP, to silnie wewnętrznie zróżnicowana grupa pod względem wielkości, dynamiki rozwoju i branży). Czołowi dostawcy rozwiązań IT w segmencie MSP świadczą podstawowe usługi instalacyjno-wdrożeniowe [Słoniewski, 2014, s. 88-89]. Niechęć do podejmowania ryzyka, aby wyjść z większą ofertą dla MSP, wynika z faktu, iż w większości przedsiębiorstwa obsługujące ten sektor są także stosunkowo małe i nie dysponują odpowiednimi środkami na ten cel.

1 Celem badania ankietowego było rozpoznanie form ekspansji zagranicznej polskich przedsiębiorstw z sektora IT oraz wpływu cyfryzacji na ich zagraniczną konkurencyjność. Zostało ono zrealizowane w ramach badań statutowych KNOP SGH w Warszawie w 2017 r. 
Tabela 1. Kapitałowe i pozakapitałowe formy internacjonalizacji - w ocenie respondentów sektora IT (w \% ogółu badanych przedsiębiorstw)

\begin{tabular}{|l|c|c|c|c|c|c|c|c|}
\hline $\begin{array}{c}\text { Przedsię- } \\
\text { biorstwa }\end{array}$ & Fuzja & Przejęcie & Alians & $\begin{array}{c}\text { Własny } \\
\text { oddział }\end{array}$ & $\begin{array}{c}\text { Joint } \\
\text { venture }\end{array}$ & $\begin{array}{c}\text { Niefor- } \\
\text { malny } \\
\text { przed- } \\
\text { stawiciel }\end{array}$ & $\begin{array}{c}\text { Fran- } \\
\text { czyza }\end{array}$ & Licencje \\
\hline \multicolumn{7}{|c|}{ Ogółem } \\
\hline Razem & 5 & 0 & 4 & 8 & 1 & 5 & 1 & 14 \\
\hline Usługowe & 2 & 0 & 3 & 10 & 2 & 3 & 0 & 15 \\
\hline Produkcyjne & 7 & 0 & 4 & 6 & 0 & 7 & 1 & 13 \\
\hline & 3 & 0 & 5 & 8 & 1 & 5 & 1 & b.d. \\
\hline Razem & 2 & 0 & 5 & 9 & 2 & 2 & 0 & b.d. \\
\hline Usługowe & 2 & 0 & 5 & 7 & 0 & 7 & 2 & b.d. \\
\hline Produkcyjne & 4 & \multicolumn{7}{|c|}{ W tym UE } \\
\hline \multicolumn{7}{|c|}{ Plany w zakresie ekspansji } \\
\hline Razem & 2 & 0 & 2 & 2 & 1 & 3 & 0 & b.d. \\
\hline
\end{tabular}

Źródło: Opracowanie własne na podstawie badań ankietowych

Brak większych zmian w ekspansji zagranicznej badanych przedsiębiorstw i jej formach, mimo poszerzenia się przestrzeni rynkowej o przestrzeń wirtualną, to także efekt niedostrzegania żadnych związanych z tym korzyści. W niewielkim stopniu respondenci pozytywnie ocenili przydatność nowych rozwiązań ICT w rozwoju ekspansji zagranicznej, wskazując, że narzędzia te są mało istotne w pokonywaniu barier: kapitałowej, transakcji finansowych, zasobowej i innowacji (odpowiednio: 78\%, 75\%, 71\%, 68\%). Niewielkie znaczenie NEMs w internacjonalizacji sprawia, że respondenci nie upatrują $w$ nich ograniczenia ryzyka działalności za granicą (93\%), w tym związanego z zaangażowaniem swych zasobów czy pokonywaniem barier instytucjonalnych (70\% i 60\% respondentów), większe znaczenie przypisując jedynie ograniczeniu ryzyka związanego z dostosowaniem oferty do potrzeb klienta (60\%). Nieliczni zwolennicy cyfryzacji upatrują w niej korzyści (mogących motywować ekspansję) przede wszystkim w: możliwości zwiększenia sprzedaży w grupie nowych i już istniejących klientów (np. przez stworzenie oferty pakietowej), lepszej obsłudze klienta i wzmocnieniu wizerunku i marki.

W modelu Uppsala, zakładającym sekwencyjne przechodzenie przedsiębiorstwa przez kolejne etapy $\mathrm{w}$ procesie jego umiędzynarodowienia, eksport traktowany jest jako pierwszy, najłatwiejszy. Niektórzy badacze [Pan, Tse, 2000, s. 538] zaliczają go do pozakapitałowych form ekspansji. W latach 2011-2014 eksport polskich firm ICT, będący wymiernym efektem ich zaangażowania w wymiarze międzynarodowym, wzrósł o 50\% (ogółem o 24\%), stanowiąc na koniec 2014 r. ok. 7,5\% wartości przychodów z eksportu ogółem. Dla większości, tj. 77\%, bada- 
nych przedsiębiorstw przychody z eksportu stanowiły 11-49\% wartości przychodów ze sprzedaży ogółem.

Przejawem wdrażania cyfrowych rozwiązań i zarazem specyfiki sektora jest duży udział w eksporcie produktów cyfrowych o charakterze niematerialnym, często w połączeniu ze świadczeniem usług, tj. oferowanie produktu w postaci pakietu (produkt i usługa) czy też poprzez personalizację produktu (odpowiednio $74 \%$ i $68 \%$ respondentów), nieco mniejszy produktów cyfrowych o charakterze materialnym (48\% respondentów). Z kolei duże znaczenie tradycyjnych pośredników w dominującej formie eksportu pośredniego badanych przedsiębiorstw to tradycyjne podejście do ekspansji zagranicznej. Z usług "tradycyjnego" krajowego pośrednika, niezależnie od kierunku eksportu, korzysta ok. 81\% respondentów, krajowego pośrednika online - 76\%, zagranicznego pośrednika online jedynie 5\%, a w przypadku eksportu do państw UE (głównego kierunku eksportu - 75\% badanych) odpowiednio 60\%,56\% i 2\%. Mając na uwadze fakt, że ok. $12 \%$ światowego handlu towarów odbywa się za pośrednictwem międzynarodowego handlu elektronicznego poprzez wykorzystanie platform, takich jak Alibaba, Amazon, eBay, Flipkart i Rakuten [McKinsey, 2016, s. 7], z których pośrednictwa korzystają miliony osób i firm na świecie, należy stwierdzić, że udział zagranicznych pośredników online w eksporcie badanych firm polskiego sektora IT jest bardzo mały.

W tych warunkach warto spojrzeć na eksport jako punkt wyjścia w rozwoju zewnętrznych relacji biznesowych, kapitałowych i pozakapitałowych, także tych inicjowanych przez KTN jako kreatorów sieci, zarówno w kraju, jak i zagranicą (internacjonalizacja bierna i czynna), które stanowią dla badanych przedsiębiorstw IT największą grupę zagranicznych klientów (92\%). Małe firmy z sektora IT dokonują ekspansji zagranicznej, bazując na sieci powiązań głównych partnerów biznesowych, często kierując się na te rynki, na których posiadają już klientów lub kooperantów (np. firmy e-commerce dystrybuujące oprogramowanie) [Forsgren, Hagström, 2007, s. 295-305]. Silni, wyspecjalizowani, lokalni partnerzy to zarazem jeden z kluczowych czynników podjęcia NEMs (różnicujący w stosunku do BIZ wiele uznawanych za wspólne uwarunkowań ich rozwoju, jak sytuacja ekonomiczna kraju goszczącego, polityka gospodarcza i ułatwienia dla biznesu). Natomiast główni partnerzy, a do takich należą KTN, narzucają podmiotom wchodzącym w skład sieci strategię poprzez świadomie kreowane powiązania oraz koordynację przepływu dóbr, informacji i wiedzy. 


\section{Podsumowanie}

Digitalizacja, istotnie poszerzając tradycyjne formy o nowe kanały i produkty (cyfrowe), sprzyja ograniczaniu tradycyjnych barier, zwiększając ryzyko wystąpienia problemów dotąd nieznanych (np. cyberatak). Stymuluje też internacjonalizację sieciową, tworzącą dobre środowisko rozwoju NEMs, której głównymi kreatorami są KTN i ich filie jako zarządzający globalnym łańcuchem wartości i inicjujący międzynarodowe relacje biznesowe partnerskich firm. Chociaż powiązania te wraz z cyfryzacją sprzyjają rozwojowi pozakapitałowych form ekspansji zagranicznej, w internacjonalizacji polskich przedsiębiorstw sektora IT NEMs (różne formy kontraktu, outsourcing, franczyza, licencje) mają niewielkie znaczenie. Wynika to przede wszystkim z niedostrzegania przez badane przedsiębiorstwa korzyści związanych z cyfryzacją biznesu w ich ekspansji zagranicznej, a także tworzonych przez nią barier, ale także ze specyfiki badanego sektora (większość to MSP). Istotne ograniczenia to: niewielkie możliwości kapitałowe (dla większości badanych wykorzystanie platform nie ogranicza bariery finansowej ekspansji zagranicznej) oraz małe doświadczenie w kreowaniu nowoczesnych rozwiązań (mały popyt wewnętrzny) i długotrwałych relacji biznesowych $\mathrm{w}$ wymiarze międzynarodowym. Oznacza to, że na obecnym etapie w dużej mierze wykorzystywane są rozwiązania konwencjonalne (duże znaczenie eksportu pośredniego i tradycyjnych pośredników), a strategia digitalizacji badanych przedsiębiorstw nie jest zintegrowana ze strategią ekspansji zagranicznej przedsiębiorstwa w zakresie rozwoju NEMs. Eksport jako wiodąca forma internacjonalizacji badanych przedsiębiorstw może, poprzez stworzone powiązania biznesowe, tworzyć dobrą podstawę dalszego rozwoju NEMs.

\section{Źródła finansowania}

Badania ankietowe wykonane (wspólnie z M. Poniatowską-Jaksch) w ramach środków na badania statutowe, nr KNOP/S17/01/17, Kolegium Nauk o Przedsiębiorstwie, Szkoła Główna Handlowa w Warszawie 2017.

Bibliografia

Bukht R., Heeks R., 2017, Defining, conceptualizing and measuring the digital economy, Development Informatics Working Paper no. 68, Centre for Development Informatics, University of Manchester, Manchester.

Chen S., 2005, Strategic Management of e-Business, John Wiley and Sons Ltd., West Sussex.

Forsgren M., Hagström P., 2007, Ignorant and impatient internationalization? The Uppsala model and internationalization patterns for Internet-related firms, Critical Perspectives on International Business, vol. 3, no. 3. 
Gartner, 2016, Building the Digital Platform. Insights From the 2016 Gartner CIO Agenda Report, Gartner 2016, https://www.gartner.com/imagesrv/cio/pdf/cio_agenda_insights_2016.pdf [dostęp: 20.10.2017].

Gray A., 2017, These are the world's 10 biggest corporate giants, WEF, https://www.weforum. org/agenda/2017/01/worlds-biggest-corporate-giants/ [dostęp: 23.10.2017].

MBASkool, 2017, Top 10 eCommerce Companies in the World 2017, http://www.mbaskool. com/fun-corner/top-brand-lists/17194-top-10-ecommerce-companies-in-the-world2017.html [dostęp: 18.11.2017].

McKinsey, 2016, Digital globalization. The new era of global flows, McKinsey Global Institute.

Pakulska T., 2017, Rynek XXI w. - w poszukiwaniu przewagi konkurencyjnej przedsiębiorstwa, [w:] Instytucje a konkurencyjność przedsiębiorstwa, red. M. Poniatowska-Jaksch, R. Sobiecki, Oficyna Wydawnicza SGH, Warszawa.

Pakulska T., Poniatowska-Jaksch M., 2016, Dekompozycja globalnego tańcucha wartości jako narzędzie realizacji strategii, [w:] Narzędzia w zarządzaniu strategicznym przedsiębiorstwem. W kierunku nowego myślenia strategicznego, red. M. Poniatowska-Jaksch, Oficyna Wydawnicza SGH, Warszawa.

Pan Y., Tse D., 2000, The Hierarchical Model of Market Entry Modes, Journal of International Business Studies, vol. 31, no. 4.

Poczta Polska, 2017, Cross border w e-commerce będzie rósł 27 proc. rok do roku, https://ecommerce. poczta-polska.pl/pl/artykuly/archiwum/2016/cross-border-w-e-commerce-bedzie-rosl27-proc-rok-do-roku [dostęp: 12.12.2017].

Poniatowska-Jaksch M., 2016, Biznes cyfrowy - wyzwania wobec strategii internacjonalizacji przedsiębiorstwa, Horyzonty Polityki, t. 7, nr 20.

Sagan M., 2017, Praktyka internacjonalizacji ekosystemów biznesowych - przykład InSite Bavaria, Ekonomika i Organizacja Przedsiębiorstwa, nr 3.

Sala S., 2005, Rozwój korporacji transnarodowych w gospodarce światowej, Przedsiębiorczość - Edukacja, nr 1.

Słoniewski T., 2014, Milion nieznanych klientów, Computerworld Top 2000, IDG.

Wieczerzycki M., 2015, Produkt cyfrowy w świetle jakościowej teorii informacji i koncepcji hylemorfizmu, Gospodarka Narodowa, nr 1.

WIR, 2011, World Investment Report 2011. Non-Equity Modes of International Production and Development, UNCTAD, New York - Geneva.

Wymbs C., 2000, How e-commerce is transforming and internationalizing service industries, Journal of Services Marketing, vol. 14, no. 6.

T. Pakulska (অ) Teresa.Pakulska@sgh.waw.pl

Instytut Rynków i Konkurencji, Szkoła Główna Handlowa w Warszawie, al. Niepodległości 162, 02-554 Warszawa, Polska 